\title{
Investigation of Turkish and Italian Students' Perceptions of the Concept of "Mathematics Teacher" through Metaphor Analysis
}

\author{
Bilge Peker ${ }^{1, *}$ \\ ${ }^{1}$ Department of Mathematics Education, Ahmet Kelesoglu Education Faculty, Necmettin Erbakan University, Konya, \\ Turkey \\ *Correspondence: Bilge Peker, Necmettin Erbakan University, Konya, Turkey. E-mail: bilge.peker@yahoo.com
}

Received: August 25, 2018

Accepted: September 17, $2018 \quad$ Online Published: October 1, 2018

doi:10.5430/wje.v8n5p63

URL: https://doi.org/10.5430/wje.v8n5p63

\begin{abstract}
The main purpose of the present research is examining the Turkish and Italian students' perceptions of the concept of "mathematics teacher" through metaphors. The study group of the research consists of 167 Turkish and 112 Italian students, the total of 279 students in the same age group. Students were asked to use another concept defining what "mathematics teacher" meant for them and to explain why. For this purpose, the data of the research were collected by each student's completing the statement "A mathematics teacher is like ..., because ...." Content analysis technique was used to analyze and interpret the obtained data. According to the findings of the research, the students developed a total of 255 valid metaphors. These metaphors are divided into 9 different conceptual categories according to their common characteristics. According to the results of the analysis, Turkish students developed metaphors on the didactic quality of mathematics teachers and Italian students developed metaphors about personality traits of mathematics teachers. Additionally, Turkish male students developed metaphors about the fact that mathematics teachers were their constant supporters. These findings are believed to have resulted from the mathematics teaching styles of math teachers and the cultural factors.
\end{abstract}

Keywords: metaphor, mathematics teacher, Turkish students, Italian students

\section{Introduction}

The future of a society depends on education and the keystones of education are teachers. Teachers are expected to play the leading role in the development of a country, in raising qualified human power, in ensuring the peace of society, in preparing individuals for social life, and in transferring the culture, values and beliefs of the society to future generations (Ozden, 1999). Teachers are not those who only give lectures and provide theoretical information in the class. Teaching is the profession of being a model and showing cognitive and affective behaviors and reflections of these in their behaviors, attitudes and relationships (Can, 1998). Teachers are also ones who touch lives. For this reason, it is important to determine how teachers, who have important influences on students' lives, are perceived (Cerit, 2008). In this context, metaphor studies are important in determining how students perceive their teachers.

"Metaphor", which is an English word, is "mecaz" in old Turkish, "benzetme, eğretileme" in modern Turkish and "istiare" in Arabic (Aydin, 2006). Aydin and Eser Unaldi (2010) define metaphor as stating a concept using comparisons and analogies in the way it is perceived (Cited in: Uzun \& Palic, 2013). Lakoff and Johnson (1980) describe metaphor as tools that help to describe a new concept or object with the features of what is known. Arnett (1999) states that metaphors are tools of perception. Metaphors find similarities between the information already existing in the mind and the new information and help to explain the new information by establishing relations with these similarities (Senemoglu, 2007). The main functions of the metaphors are capturing a wide range of information, interpreting them, and providing benefits in dealing with uncertainty (Erdem \& Satir, 2000). At the same time, metaphors can be used to identify facts and to encourage re-conceptualizing of problematic situations as they affect how we perceive situations and events (Goldstein, 2005). Arslan and Bayrakci (2006) stated that the metaphors, defined as a powerful mental mapping and modeling mechanism individuals use to understand their worlds, are a teaching tool, because metaphors help to understand abstract concepts in a concrete way and increase the memorability of the issues. They also develop creativity among students. The two basic principles of teaching are 
going from the known to the unknown and from concrete to abstract. Metaphors use concrete examples to explain abstract concepts.

Mathematics has always been a subject considered difficult. This perception of the subject course also affects the achievements of the students, because people's feelings and thoughts influence their behaviors. It has been observed that this prejudice against mathematics subject has also been developed against mathematics teachers. For this reason, studies on how students perceive mathematics teachers have been conducted.

Fleener, Pourdavood and Fry (1995) asked pre-service mathematics teachers to develop metaphors for different roles and tasks of mathematics teachers. According to their findings, the most frequently developed metaphors were; mentor, expert, leader, director and mother.

Yilmaz, Gocen and Yilmaz (2013) identified perceptions of the concept of teacher of pre-service teachers studying in five different departments through the metaphors. According to their findings, pre-service teachers perceived the concept of teacher with a very broad metaphoric perception, because pre-service teachers defined the teacher with such known metaphors as family, parent, guide, gardener, light as well as different metaphor as social insurance, minimum wage, the first three articles of the constitution.

Sahin (2013) studied the metaphors related to the concepts of mathematics teacher, mathematics and mathematics subject developed by pre-service teachers. Pre-service teachers from 9 different branches participated in the research. According to the findings, the most frequent metaphors developed for mathematics teacher were very knowledgeable and authoritative. In addition, it was found that the perceptions of the students differed according to their departments. Pre-service science and technology, pre-school and classroom teachers, who said that they were successful and ambitious, stated that they found mathematics fun, and mathematics teachers knowledgeable, affectionate and successful. Pre-service arts, social sciences and music teachers preferred more negative metaphors than pre-service teachers from other departments.

Toluk Ucar, Akkas, Piskin and Tasci (2010) studied the beliefs of elementary school students about mathematics, mathematics teachers and mathematicians. The researchers conducted interviews with the students and asked them to draw pictures of their dream mathematicians. Students' negative opinions about mathematics teachers, found in the research, are interesting. The students reflected the math teachers in their drawings as people who were threatening, violent, humiliating, trying to force students to do something with weapons in their hands. Those, who used positive features, stated that they described the mathematics teacher they wanted to have. According to the findings of the research, students perceived mathematicians as people engaged in numbers, working constantly, non-social, introverted, tough and angry.

A similar study was conducted by Sengul, Katranci and Cantimer (2014). They found that the concept of mathematics teacher couldn't be defined with one single metaphor. For this reason, researchers collected the 137 different metaphors produced by students under 7 conceptual categories. Students emphasized the negative aspects of mathematics teachers with their metaphors such as blind knots, traffic accidents and nervous, while emphasizing the knowledge, instruction and guidance of mathematics teachers with positive metaphors such as flowers, angels, professors and books. It was found that, while students' perceptions of mathematics teachers varied significantly by class grades, there were no differences by gender.

Metaphors vary from culture to culture (Parin, 2017). The meaning of a concept in a culture may differ in another culture. Educational systems can also affect metaphors. Noyes (2004) stated that the way of teaching mathematics changed in accordance with geography and culture, and this change caused different perceptions of mathematics. Therefore, the metaphor used by students, changed between countries, even within the countries. Kilic (2010) used metaphors to determine Turkish and Belgian pre-service mathematics teachers' opinions of mathematics. According to the findings of the research, Turkish pre-service teachers used emotional metaphors to define mathematics, while Belgian pre-service teachers used action metaphors. It was inferred from this finding that cultural factor and the practices educational systems are the possible reasons for different metaphors.

Kilic and Yelken Yanpar (2013) determined Turkish and Belgian pre-service teachers' opinions of mathematics through metaphors. The findings of the research were in agreement with the findings of the study mentioned before. Turkish pre-service teachers preferred emotional metaphors to define mathematics, while Belgian pre-service teachers preferred action metaphors. The researchers stated that the difference could be resulted from cultural differences, geographical location, mathematics learning style, past experiences, social and educational interests. 


\section{Objective}

The purpose of the present research is presenting the perceptions of the concept of mathematics teacher of students, who study in Turkey and Italy through metaphors. Within the scope of this general objective, answers to the following questions are sought:

1) Through which metaphors do the Turkish students define their perceptions of the concept of "mathematics teacher" and under what categories can these metaphors be collected?

2) Through which metaphors do the Italian students define their perceptions of the concept of "mathematics teacher" and under what categories can these metaphors be collected?

3) What are the common categories created by the common features of metaphors developed by Turkish and Italian students regarding the concept of "mathematics teacher"?

4) Are there differences between the categories, in which the metaphors developed by the students from two countries are collected?

\section{Method}

\subsection{Research Model}

The present research is a phenomenological modeled qualitative research, which determines the perceptions of the concept of "mathematics teacher" of students from two countries through metaphor analysis method.

According to Yildirim and Simsek (2008), phenomenological research is the revealing and interpretation of individual perceptions of a phenomenon. The purpose of the present research is revealing and interpreting the perceptions of the concept of mathematics teacher through metaphors.

\subsection{Study Group}

The study group of the research consists of 167 students studying in Turkey and 112 students studying in Italy, the total of 279 students of the same age, selected through random sampling method.

\subsection{Data Collection and Analysis}

The students, who participated in the present research, were asked to use another concept that explains what "Mathematics Teacher" means for them, to explain why, and to write their thoughts, concentrating only on one single metaphor. With this purpose, students were provided with a form with the statement "Mathematics teacher is like ..., because ..." on it and were asked to fill in these forms. This study was formed with data from the EU Project entitled "Innovative Mathematics Teaching - Exchanging Horizons". The steps of analyzing and interpreting the mental images developed by the students were organized according to Saban (2009). The analysis and interpretation of the data consists of five steps.

\subsubsection{Coding and Sorting Step}

The mental images produced by the students participating in the research were arranged in alphabetical order to create a list. Then, it was checked whether students expressed the metaphor they wrote clearly. At this step, the forms with no metaphor, empty forms and forms with metaphors but no justifications were excluded. For this reason, 24 forms were excluded from the research.

\subsubsection{Sample Metaphor Compilation Step}

At this step, every mental image is separated into parts using techniques of "mental image analysis" (Saban, 2009) and "content analysis" (Yildirim \& Simsek, 2008). In accordance with the purpose of this step, the mental images written by students were re-read and reviewed, and the (1) resembling, (2) resemblee and the relationship between resembling and resemblee were analyzed for each mental image. In this scope, 130 metaphors from 167 Turkish students, and 85 metaphors from 112 Italian students were collected.

\subsubsection{Category Development Step}

At this step, conceptual categories were developed for the metaphors developed for the concept of "mathematics teacher", by checking the reasons of the mental images of the students participating in the research. 9 different conceptual categories were identified for Turkish students and 8 for Italian students.

\subsubsection{Reliability and Validity Step}

To ensure the reliability of the research, expert opinion was consulted and the expert was asked to investigate 
whether the metaphors collected under different conceptual categories by the researcher represented the related conceptual categories. The matches, formed by the expert and the researcher, were compared. Agreement and disagreement numbers in comparisons were defined and the reliability of the research was calculated with Miles and Huberman's (1994) formula (Reliability = agreement / (agreement + disagreement) $x 100)$.

In qualitative studies, the agreement between the expert and researcher evaluations being $90 \%$ and over, provides desired reliability (Saban, 2009). Because the expert matched 9 metaphors from Turkish students with other categories, the calculations provided $93 \%$ (Reliability $=121 /(121+9) \times 100)$ reliability for Turkish students; and because the expert matched 7 metaphors from Italian students with other categories, the calculations provided $92 \%$ (Reliability $=78 /(78+7) \times 100)$ reliability for Italian students.

\subsubsection{Transferring Data to Computer Environment Step}

After 130 metaphors created by Turkish students collected under 9 categories, and 85 metaphors created by Italian students were collected under 8 different categories and obtained data were transferred to the computer environment. The number (f) and percent (\%) of students represented were calculated. As a result of these calculations, the metaphors and the categories in which these metaphors are represented were tabulated. A table was created for the comparison of Turkish and Italian students.

\section{Results}

\subsection{Conceptual Categories and Metaphors for Turkish Students}

Table 1. Distribution of Metaphors Belonging to Turkish Male Students by Categories

\begin{tabular}{|c|c|c|c|c|c|}
\hline Categories & $\mathrm{f}$ (Student) & $\%$ & Metaphors & $\mathrm{f}$ (Metaphor) & $\%$ \\
\hline Didactic quality & 22 & 32.35 & $\begin{array}{l}\text { The tree branch that gives the most plums } 1 \text {, bee } \\
1 \text {, simple } 1 \text {, computer } 1 \text {, tree rooted next to a } \\
\text { waterfall } 1 \text {, farmer } 1 \text {, drop } 1 \text {, instructor } 1 \text {, doctor } \\
1 \text {, sun } 2 \text {, box } 1 \text {, machine } 1 \text {, math terms } 1 \text {, master } \\
\text { of mathematics } 1 \text {, angel } 1 \text {, cotton-hearted } 1 \text {, robot } \\
1 \text {, complete entertainment and teaching resource } \\
1 \text {, radish } 2 \text {, sweet } 1\end{array}$ & 20 & 33.90 \\
\hline Guidance & 5 & 7.35 & $\begin{array}{l}\text { Very good person } 3 \text {, someone who makes easier } \\
\text { our daily life } 1 \text {, guide } 1\end{array}$ & 3 & 5.08 \\
\hline Knowledge/intelligence & 15 & 22.06 & $\begin{array}{l}\text { Machine of mind and question } 1 \text {, smart person } 1 \text {, } \\
\text { source of information } 1 \text {, information chest } 1 \text {, } \\
\text { someone who knows everything } 1 \text {, scholar } 2 \text {, } \\
\text { scientist } 1 \text {, Rubik's cube } 1 \text {, intelligent person } 2 \text {, } \\
\text { mathematics 2, question bank 1, box of } \\
\text { intelligence } 1\end{array}$ & 12 & 20.34 \\
\hline Personality traits & 6 & 8.82 & $\begin{array}{l}\text { Bitter-sweet pepper } 1 \text {, walnut } 1 \text {, chum } 2 \text {, sugar } 1 \text {, } \\
\text { angel } 1\end{array}$ & 5 & 8.47 \\
\hline Physical characteristics & 0 & 0.00 & - & 0 & 0.00 \\
\hline Constant supporter & 5 & 7.35 & Moon 1 , close sibling 1 , sea 1 , mother 2 & 4 & 6.78 \\
\hline Valuableness & 12 & 17.65 & $\begin{array}{l}\text { Our family } 1 \text {, cook } 1 \text {, source of information } 1 \text {, } \\
\text { computer } 1 \text {, flower } 1 \text {, universe } 1 \text {, rose } 1 \text {, lifeguard } \\
1 \text {, water } 1 \text {, soil } 1 \text {, feather for chicken } 1 \text {, our basic } \\
\text { resource } 1\end{array}$ & 12 & 20.34 \\
\hline Super-natural/hero & 0 & 0.00 & - & 0 & 0.00 \\
\hline Other & 3 & 4.41 & Myself 1 , tulip 1 , banana 1 & 3 & 5.08 \\
\hline Total & 68 & 100.00 & & 59 & 100.00 \\
\hline
\end{tabular}


According to the Table 1,32.35\% of the Turkish male students produced metaphors of the "didactic quality" category, which accounted for $33.90 \%$ of the metaphors produced by these Turkish male students. This is followed by "knowledge/intelligence" category metaphors with $22.06 \%$. Knowledge/intelligence category metaphors formed the $20.34 \%$ of the metaphors produced by Turkish male students.

Examples of the metaphors produced by Turkish male students are as follows:

"Mathematics teacher is like a bitter-sweet pepper, because they are sometimes angry sometimes calm."

"Mathematics teacher is like a box, because they store information and distributes to students."

"Mathematics teacher is like a close sibling, because they never want us hurt, are always with us."

"Mathematics teacher is like a guide, because they help us go further."

"Mathematics teacher is like a scientist, because they keep so much information on mind."

According to the justifications given for the metaphors produced, some students mentioned about the didactic quality of the mathematics teacher, some students mentioned that they were intelligent, and some stated that they were supportive at all times. "Other" category was formed for metaphors that could not be included in any category, or were categories on their own. As far as can be inferred from the metaphors in general terms, Turkish male learners have positive and negative perceptions about mathematics teachers. This difference can be resulted from individual differences.

Table 2. Distribution of Metaphors Belonging to Turkish Female Students by Categories

\begin{tabular}{|c|c|c|c|c|c|}
\hline Categories & $\mathrm{f}$ (Student) & $\%$ & Metaphors & f(Metaphor) & $\%$ \\
\hline Didactic quality & 19 & 22.35 & $\begin{array}{l}\text { Mother } 4 \text {, brain } 1 \text {, water } 2 \text {, very good narrator } 1 \text {, } \\
\text { narrator } 1 \text {, a full sack } 1 \text {, sun } 2 \text {, someone who teaches } \\
\text { the processes and problems of life } 1 \text {, teaches life } 1 \text {, } \\
\text { book author } 1 \text {, subject } 1 \text {, happiness } 1 \text {, oxygen tube } 1 \text {, } \\
\text { princess } 1\end{array}$ & 14 & 19.72 \\
\hline Guidance & 11 & 12.94 & $\begin{array}{l}\text { Person who taught us the right way } 1 \text {, person who } \\
\text { taught us the rules of life } 1 \text {, great person } 1 \text {, very good } \\
\text { router } 1 \text {, teacher of life } 2 \text {, guide of experience } 1 \text {, } \\
\text { facilitating life } 1 \text {, light } 1 \text {, user guide } 1 \text {, life guide } 1\end{array}$ & 10 & 14.08 \\
\hline Knowledge/intelligence & 18 & 21.18 & $\begin{array}{l}\text { Tree } 1 \text {, brain } 1 \text {, information store } 1 \text {, information } 1 \text {, } \\
\text { scientist } 2 \text {, very knowledgeable } 1 \text {, genius } 1 \text {, the } \\
\text { smartest person in the world } 1 \text {, book author } 1 \text {, math } \\
\text { bee } 1 \text {, knows everthing in math } 1 \text {, school } 1 \text {, sumo } \\
\text { fighter } 1 \text {, question bank } 2 \text {, intelligence } 2\end{array}$ & 15 & 21.13 \\
\hline Personality traits & 24 & 28.24 & $\begin{array}{l}\text { Hot and not hot shish kebab } 1 \text {, smart board } 1 \text {, } \\
\text { understanding } 1 \text {, friend } 1 \text {, sometimes sour sometimes } \\
\text { sweet candy } 1 \text {, angel } 3 \text {, like the blood that fills our } \\
\text { brain } 1 \text {, nervous creamer } 1 \text {, Pepee } 1 \text {, water } 1 \text {, chum } 2 \text {, } \\
\text { sour face } 1 \text {, Elif } 1 \text {, received full marks from the most } \\
\text { difficult gourmets } 1 \text {, joke machine } 1 \text {, matchless } 1 \text {, } \\
\text { happiness } 1 \text {, sweet } 1 \text {, time } 1 \text {, tangled thread } 1 \text {, dull } \\
\text { boring caged bird } 1\end{array}$ & 21 & 29.58 \\
\hline Physical characteristics & 1 & 1.18 & Flower 1 & 1 & 1.41 \\
\hline Constant supporter & 0 & 0.00 & - & 0 & 0.00 \\
\hline Valuableness & 8 & 9.41 & $\begin{array}{l}\text { Sine qua non } 1 \text {, famous } 1 \text {, flower } 1 \text {, bread } 1 \text {, life } 2 \text {, } \\
\text { telling our life } 1 \text {, building foundation } 1\end{array}$ & 7 & 9.86 \\
\hline Super-natural/hero & 2 & 2.35 & Wizard 2 & 1 & 1.41 \\
\hline Other & 2 & 2.35 & Rose 1 , taboo 1 & 2 & 2.82 \\
\hline Total & 85 & 100.00 & & 71 & 100.00 \\
\hline
\end{tabular}


As presented in the Table 2, 28.24\% of the Turkish female students produced metaphors included in the category of "personality traits". This makes up the $29.58 \%$ of the metaphors produced by Turkish female students. This is followed by metaphors included in the "didactic quality" category with $22.35 \%$. Metaphors included in the "didactic quality" category make up the $19.72 \%$ of the metaphors produced by Turkish female students.

Some of the metaphors produced by Turkish female students are as follows:

"Mathematics teacher is like a hot and not hot shish kebab, because they are sometimes hot, namely bad and sometimes not hot, namely good."

"Mathematics teacher is like a tangled thread, because they are difficult to understand."

"Mathematics teacher is like a dull, boring caged bird, because they are pathetic captives of mathematics and boring. "

"Mathematics teacher is like a life guide, because they guide us in everything about life."

"Mathematics teacher is like water, because they are mild-mannered."

"Mathematics teacher is like bread, because they are indispensable."

"Mathematics teacher is like the sun, because they illuminate us with their knowledge."

According to the justifications given for the metaphors produced, some students mentioned about the personality traits of mathematics teachers, while some mentioned their didactic quality and some about their knowledge. "Other" category was formed for metaphors that could not be included in any category, or were categories on their own. As far as can be inferred from the metaphors in general terms, Turkish female students have positive and negative perceptions about mathematics teachers. This difference in perceptions can be resulted from individual differences.

Examining the metaphors produced by Turkish male and female students, it can be observed that $33.90 \%$ of the metaphors produced by male students were about the didactic quality of mathematics teachers, while $29.58 \%$ of the metaphors produced by female students were about the personality traits of mathematics teachers.

Table 3. Distribution of Metaphors Belonging to Turkish Students by Categories

\begin{tabular}{lcccccc}
\hline \multicolumn{1}{c}{ Categories } & \multicolumn{2}{c}{ Male } & \multicolumn{2}{c}{ Female } & \multicolumn{2}{c}{ Total } \\
\hline Didactic quality & $\mathrm{f}$ & $\%$ & $\mathrm{f}$ & $\%$ & $\mathrm{f}$ & $\%$ \\
Guidance & 22 & 32.35 & 19 & 22.35 & 41 & 26.80 \\
Knowledge/intelligence & 5 & 7.35 & 11 & 12.94 & 16 & 10.46 \\
Personality traits & 15 & 22.06 & 18 & 21.18 & 33 & 21.57 \\
Physical characteristics & 6 & 8.82 & 24 & 28.24 & 30 & 19.61 \\
Constant supporter & 0 & 0.00 & 1 & 1.18 & 1 & 0.65 \\
Valuableness & 5 & 7.35 & 0 & 0.00 & 5 & 3.27 \\
Super-natural/hero & 12 & 17.65 & 8 & 9.41 & 20 & 13.07 \\
Other & 0 & 0.00 & 2 & 2.35 & 2 & 1.31 \\
Total & 3 & 4.41 & 2 & 2.35 & 5 & 3.27 \\
\hline
\end{tabular}

As can be seen in the Table 3, male students did not produce any metaphors included in the physical characteristics or super-natural categories, and female students did not produce any metaphors included in the constant supporter category. This finding can be resulted from gender differences.

\subsection{Conceptual Categories and Metaphors for Italian Students}


Table 4. Distribution of Metaphors Belonging to Italian Male Students by Categories

\begin{tabular}{|c|c|c|c|c|c|}
\hline Categories & $\mathrm{f}$ (Student) & $\%$ & Metaphors & $\mathrm{f}(($ Metaphor $)$ & $\%$ \\
\hline Didactic quality & 11 & 19.30 & $\begin{array}{l}\text { Worker } 1 \text {, genius } 1 \text {, valuable } 1 \text {, } \\
\text { lessons } 1 \text {, newspaper } 1 \text {, church } 2 \text {, } \\
\text { leader } 1 \text {, angel } 1 \text {, field where only } \\
\text { numbers are planted } 1 \text {, fox } 1\end{array}$ & 10 & 20.83 \\
\hline Guidance & 3 & 5.26 & Coach 1 , decent 1 , guide 1 & 3 & 6.25 \\
\hline Knowledge/intelligence & 3 & 5.26 & Computer 1, Einstein 1, book 1 & 3 & 6.25 \\
\hline Personality traits & 27 & 47.37 & $\begin{array}{l}\text { Angel and Demon } 3 \text {, White and } \\
\text { black } 1 \text {, computer } 1 \text {, monster } 1 \text {, } \\
\text { ice } 1 \text {, witch } 2 \text {, walnut cake } 1 \text {, } \\
\text { flower } 1 \text {, birthday cake } 1 \text {, } \\
\text { thoughtful chicken } 1 \text {, dragon } 2 \text {, } \\
\text { sun } 1 \text {, sunglasses } 1 \text {, weather } \\
\text { condition } 1 \text {, cake } 1 \text {, dog } 1 \text {, death } \\
1 \text {, party } 1 \text {, sugar } 1 \text {, sweet } 1 \text {, rabbit } \\
1 \text {, lazy animal } 1 \text {, turmeric } 1\end{array}$ & 23 & 47.92 \\
\hline Physical characteristics & 5 & 8.77 & Flower 2, artwork 1, Wolverine 2 & 3 & 6.25 \\
\hline Constant supporter & 0 & 0.00 & - & 0 & 0.00 \\
\hline Valuableness & 1 & 1.75 & Head 1 & 1 & 2.08 \\
\hline Super-natural/hero & 6 & 10.53 & $\begin{array}{l}\text { Harry Potter and Hermione } 1 \text {, } \\
\text { Hermione } 3 \text {, spider woman } 1 \text {, } \\
\text { God } 1\end{array}$ & 4 & 8.33 \\
\hline Other & 1 & 1.75 & Water 1 & 1 & 2.08 \\
\hline Total & 57 & 100.00 & & 48 & 100.00 \\
\hline
\end{tabular}

According to the Table 4, 47.37\% of the Italian male students produced metaphors of the "personality traits" category, which makes up $47.92 \%$ of the metaphors produced by these Italian male students. This is followed by "didactic quality" category metaphors with $19.30 \%$. Metaphors included in this category formed the $20.83 \%$ of the metaphors produced by Italian male students.

Some examples of the metaphors produced by Italian male students are as follows:

"Mathematics teacher is like the church, because they teach important things but they are boring."

“Mathematics teacher is like a dragon, because they often get angry but can also be good.”

"Mathematics teacher is like a newspaper, because they give information about things we don't know."

"Mathematics teacher is like the God, because they have super-natural talents."

"Mathematics teacher is like Wolverine, because they are very strong."

"Mathematics teacher is like ice, because they are rarely happy."

"Mathematics teacher is like a genius, because they always teach new things."

As far as can be inferred from the metaphors in general terms, Italian male students have positive and negative perceptions about mathematics teachers. This difference in perceptions can be resulted from individual differences. Similarly, "Other" category was formed for metaphors that could not be included in any category, or were categories on their own. 
Table 5. Distribution of Metaphors Belonging to Italian Female Students by Categories

\begin{tabular}{|c|c|c|c|c|c|}
\hline Categories & $\mathrm{f}$ (Student) & $\%$ & Metaphors & f(Metaphor) & $\%$ \\
\hline Didactic quality & 3 & 6.67 & Mother 1 , a big number 1 , worker 1 & 3 & 8.11 \\
\hline Guidance & 3 & 6.67 & Mad 1, parents 1 , internet 1 & 3 & 8.11 \\
\hline Knowledge/intelligence & 1 & 2.22 & Computer 1 & 1 & 2.70 \\
\hline Personality traits & 23 & 51.11 & $\begin{array}{l}\text { Moon } 1 \text {, sunflower and star } 1 \text {, my } \\
\text { friend } 1 \text {, terrible person } 1 \text {, white } \\
\text { cloud } 1 \text {, sun } 1 \text {, cat } 1 \text {, cake and lion } 1 \text {, } \\
\text { playground } 1 \text {, daisy } 1 \text {, mother of the } \\
\text { class } 1 \text {, eraser } 1 \text {, sugar } 3 \text {, leaf } 1 \text {, } \\
\text { crossfire } 1 \text {, yin yang } 1 \text {, rainbow } 1 \text {, a } \\
\text { game you enjoy every moment } 1 \text {, star } \\
1 \text {, box } 1 \text {, Sylvester } 1\end{array}$ & 21 & 56.76 \\
\hline Physical characteristics & 5 & 11.11 & Flower 3, rabbit 2 & 2 & 5.41 \\
\hline Constant supporter & 0 & 0.00 & - & 0 & 0.00 \\
\hline Valuableness & 8 & 17.78 & $\begin{array}{l}\text { Bee } 1 \text {, president } 1 \text {, water } 1 \text {, manager } \\
1 \text {, fairy } 4\end{array}$ & 5 & 13.51 \\
\hline Super-natural/hero & 1 & 2.22 & Hermione 1 & 1 & 2.70 \\
\hline Other & 1 & 2.22 & My sister 1 & 1 & 2.70 \\
\hline Total & 45 & 100.00 & & 37 & 100.00 \\
\hline
\end{tabular}

As can be seen from the Table 5, produced metaphors were collected under 8 categories. $51.11 \%$ of Italian female students produced metaphors included in the "personality traits" category. On the other hand, they did not produce any metaphors included in the constant supporter category. This is followed by metaphors in "valuableness" category with $17.78 \%$. Metaphors included in the valuableness category make up $13.51 \%$ of the categories produced by Italian female students.

Some examples of the metaphors produced by Italian female students are as follows:

"Mathematics teacher is like a sunflower and a star, because they are always happy and bright."

"Mathematics teacher is like water, because they are vital for life."

"Mathematics teacher is like parents, because they want the best for us even they are bad."

"Mathematics teacher is like yin yang, because they are fun when white and bad when black."

"Mathematics teacher is like a worker, because they lay the foundation and we build the house around us."

Examining the metaphors produced by Italian male and female students, it can be observed that both groups produced the most metaphors included in the personality traits category. Metaphors of this category make up the $47.92 \%$ of the metaphors produced by male students and $56.76 \%$ of the metaphors produced by female students.

Table 6. Distribution of Metaphors Belonging to Italian Students by Categories

\begin{tabular}{lcccccc}
\hline \multirow{2}{*}{ Categories } & \multicolumn{2}{c}{ Male } & \multicolumn{2}{c}{ Female } & \multicolumn{2}{c}{ Total } \\
\cline { 2 - 7 } & $\mathrm{f}$ & $\%$ & $\mathrm{f}$ & $\%$ & $\mathrm{f}$ & $\%$ \\
\hline Didactic quality & 11 & 19.30 & 3 & 6.67 & 14 & 13.73 \\
Guidance & 3 & 5.26 & 3 & 6.67 & 6 & 5.88 \\
Knowledge/intelligence & 3 & 5.26 & 1 & 2.22 & 4 & 3.92 \\
Personality traits & 27 & 47.37 & 23 & 51.11 & 50 & 49.02 \\
Physical characteristics & 5 & 8.77 & 5 & 11.11 & 10 & 9.80 \\
Constant supporter & 0 & 0.00 & 0 & 0.00 & 0 & 0.00 \\
Valuableness & 1 & 1.75 & 8 & 17.78 & 9 & 8.82 \\
Super-natural/hero & 6 & 10.53 & 1 & 2.22 & 7 & 6.86 \\
Other & 1 & 1.75 & 1 & 2.22 & 2 & 1.96 \\
Total & 57 & 100.00 & 45 & 100.00 & 102 & 100.00 \\
\hline
\end{tabular}


As presented in the Table 6, male and female students produced more metaphors included in the personality traits category. Similarly, both group students did not produce any metaphors included in "constant supporter" category.

\subsection{Common and Different Conceptual Categories for Turkish and Italian Students}

Table 7. Conceptual Categories of Metaphors of Turkish and Italian Students

\begin{tabular}{lcccc}
\hline \multirow{2}{*}{ Categories } & \multicolumn{2}{c}{ Turkish Students } & \multicolumn{2}{c}{ Italian Students } \\
\cline { 2 - 5 } \multicolumn{1}{c}{ f } & $\%$ & $\mathrm{f}$ & $\%$ \\
\hline Didactic quality & 41 & 26.80 & 14 & 13.73 \\
Guidance & 16 & 10.46 & 6 & 5.88 \\
Knowledge/intelligence & 33 & 21.57 & 4 & 3.92 \\
Personality traits & 30 & 19.61 & 50 & 49.02 \\
Physical characteristics & 1 & 0.65 & 10 & 9.80 \\
Valuableness & 20 & 13.07 & 9 & 8.82 \\
Super-natural/hero & 2 & 1.31 & 7 & 6.86 \\
Constant supporter & 5 & 3.27 & 0 & 0.00 \\
\hline
\end{tabular}

As shown in Table 7:

- Turkish students produced more metaphor images included in the "didactic quality" category than Italian students.

- Italian students produced more metaphor images included in the "personality traits" category than Turkish students.

- Turkish students produced more metaphor images included in the "knowledge/intelligence" category than Italian students.

- Italian students produced more metaphor images included in the "physical characteristics" category than Turkish students.

- Turkish students produced more metaphor images included in the "guidance" category than Italian students.

- Italian students produced more metaphor images included in the "super-natural/hero" category than Turkish students.

- Unlike Italian students, Turkish students developed metaphors included in "constant supporter" category.

Table 8. Conceptual Categories of Metaphors of Turkish and Italian Male and Female Students

\begin{tabular}{lcccccccccccc}
\hline \multirow{2}{*}{ Categories } & \multicolumn{4}{c}{ Turkish Students } & \multicolumn{4}{c}{ Italian Students } \\
\cline { 2 - 16 } & \multicolumn{2}{c}{ Male } & \multicolumn{3}{c}{ Female } & \multicolumn{2}{c}{ Total } & \multicolumn{3}{c}{ Male } & \multicolumn{3}{c}{ Female } & \multicolumn{2}{c}{ Total } \\
& $\mathrm{f}$ & $\%$ & $\mathrm{f}$ & $\%$ & $\mathrm{f}$ & $\%$ & $\mathrm{f}$ & $\%$ & $\mathrm{f}$ & $\%$ & $\mathrm{f}$ & $\%$ \\
\hline Didactic quality & 22 & 32.35 & 19 & 22.35 & 41 & 26.80 & 11 & 19.30 & 3 & 6.67 & 14 & 13.73 \\
Guidance & 5 & 7.35 & 11 & 12.94 & 16 & 10.46 & 3 & 5.26 & 3 & 6.67 & 6 & 5.88 \\
Knowledge/intelligence & 15 & 22.06 & 18 & 21.18 & 33 & 21.57 & 3 & 5.26 & 1 & 2.22 & 4 & 3.92 \\
Personality traits & 6 & 8.82 & 24 & 28.24 & 30 & 19.61 & 27 & 47.37 & 23 & 51.11 & 50 & 49.02 \\
Physical characteristics & 0 & 0.00 & 1 & 1.18 & 1 & 0.65 & 5 & 8.77 & 5 & 11.11 & 10 & 9.80 \\
Valuableness & 12 & 17.65 & 8 & 9.41 & 20 & 13.07 & 1 & 1.75 & 8 & 17.78 & 9 & 8.82 \\
Super-natural/hero & 0 & 0.00 & 2 & 2.35 & 2 & 1.31 & 6 & 10.53 & 1 & 2.22 & 7 & 6.86 \\
Constant supporter & 5 & 7.35 & 0 & 0.00 & 5 & 3.27 & 0 & 0.00 & 0 & 0.00 & 0 & 0.00 \\
Other & 3 & 4.41 & 2 & 2.35 & 5 & 3.27 & 1 & 1.75 & 1 & 2.22 & 2 & 1.96 \\
Total & 68 & 100.00 & 85 & 100.00 & 153 & 100.00 & 57 & 100.00 & 45 & 100.00 & 102 & 100.00 \\
\hline
\end{tabular}

\section{Discussion and Conclusion}

The purpose of the present research was determining Turkish and Italian students' perceptions of mathematics teacher through metaphors and studying the similarities and differences between them.

In this scope, Turkish male students developed a total of 59 different metaphors for mathematics teachers and Turkish female students developed a total of 71 different metaphors for mathematics teachers, so, Turkish students developed 
the total of 130 different metaphors. Italian male students developed a total of 48 different metaphors for mathematics teachers, Italian female students developed a total of 37 different metaphors for mathematics teachers, so, Italian students developed the total of 85 different metaphors. The total of 215 different valid metaphors were obtained in the present research.

The metaphors produced by the Italian students, who participated in the present research, were collected under 8 categories as "didactic quality", "guidance", "knowledge/intelligence", "personality traits", "physical characteristics", "valuableness", "super-natural/hero" and "other". Metaphors produced by Turkish students were collected under 9 categories, with one addition "constant supporter". Parin (2017) stated that metaphors differ from culture to culture, which explains that metaphors produced by Turkish students formed one extra conceptual category as "constant supporter". Kilic and Yelken Yanpar (2013) defined Turkish and Belgian pre-service teachers' opinions of mathematics through metaphors. According to their findings, Turkish pre-service teachers preferred emotional metaphors to define mathematics, while Belgian pre-service teachers preferred action metaphors. Researchers stated that the reason for these differences could be cultural differences, geographical location, mathematics learning style, past experiences, social and educational interests. This finding is in agreement with the findings of the present research.

According to the findings of the present research, most of the metaphors produced by Turkish students $(26.80 \%)$ were included in the "didactic quality" category $(f=41)$, while most of the metaphors produced by Italian students (49.02\%) were included in the "personality traits" category $(f=50)$. This finding could have resulted from the differences in the methods preferred by mathematics teachers in mathematics teaching. Additionally, the relationships between developed metaphors and their justifications show that there is a relationship between students' perspective of mathematics and perspective of mathematics teacher. This can be observed from the metaphors related to the negative personality traits of mathematics teachers. Akbasli, Uredi, Yolcu and Logoglu Kosece (2017) stated in their study conducted to reveal the secondary school students' perceptions of the concepts of "mathematics teacher" and "mathematics subject" that attitudes toward mathematics subjects and mathematics teachers affected each other, which is in agreement with the findings of the present research. In terms of the perception of Turkish and Italian students, findings of the study conducted by Noyes (2004) are in agreement with the findings of the present research. Noyes (2004) reported that the way mathematics was taught differed by geography and culture, and this difference resulted in differences in perceptions of mathematics.

According to the findings of Sahin (2013), mathematics teachers were mostly perceived with very knowledgeable and authoritarian metaphors. Turkish and Italian students, who participated in the present research, also produced similar metaphors under the categories of "knowledge/intelligence" and "personality traits".

Fleener et al. (1995), who asked pre-service mathematics teacher to produce metaphors for the different roles and duties of mathematics teachers, reported that most frequently produced metaphors were mentor, expert, leader, manager and mother metaphors. One of the Italian students produced the "leader" metaphor and one Italian and 6 Turkish students produced the "mother" metaphor.

The findings of the present research show that, students have positive and negative perceptions of mathematics teacher. Toluk Ucar et al. (2010) studied the beliefs of elementary school students about mathematics, mathematics teachers and mathematicians. Students' negative opinions about mathematics teachers, found in their research, are interesting. Those, who used positive features, stated that they described the mathematics teacher they wanted to have. In their study, Yetim Karaca and Ada (2018) reported that themes represented with most students were "mathematics teacher as an intelligent person" and "mathematics teacher as a bad person". They found that students didn't like their mathematics teachers even they considered them as intelligent people.

A similar study was conducted by Sengul et al. (2014). The researchers tried to find out secondary school students' perceptions of the concept of mathematics teacher through metaphors. Students emphasized the negative aspects of mathematics teachers with their metaphors such as blind knots, traffic accidents and nervous, while emphasizing the knowledge, instruction and guidance of mathematics teachers with positive metaphors such as flowers, angels, professors and books.

Briefly stated, metaphors and related categories on the mathematics teacher found in the related literature are in agreement with the ones in the present research. Because it is believed that the role of students' love for their mathematics teachers is important in their developing positive attitudes towards mathematics subject, it is suggested that mathematics teachers are understanding, calm and they empathize with their students, as it was found that most metaphors produced by both group students were included in "personality traits" category $(f=80)$. 


\section{Acknowledgement}

This study is the extended version of the one which was presented as an oral presentation at the conference entitled "International Conference on Mathematics, An Istanbul Meeting for World Mathematicians" held in Istanbul between 3-6 July 2018.

\section{References}

Akbasli, S., Uredi, L., Yolcu, H., \& Logoglu Kosece, P. (2017). Analyzing the metaphorical perception of secondary education students related to mathematics teacher and mathematics course. Kastamonu Eğitim Dergisi, 25(6), 2283-2294.

Arnett, R. C. (1999). Metaphorical guidance: Administration as building and renovation. Journal of Educational Administration, 37(1), 80-89. https://doi.org/10.1108/09578239910253953

Arslan, M., \& Bayrakci, M. (2006). Metaforik düşünme ve öğrenme yaklaşımının eğitim-öğretim açısından incelenmesi. Millî Ĕ̆itim Dergisi, 171, 100-108.

Aydin, F., \& Eser Unaldi, U. (2010). Coğrafya öğretmen adaylarının “coğrafya” kavramına ilişkin algılarının metaforlar yardımiyla analizi. International Online Journal of Educational Sciences, 2(2), 600-622.

Aydin, I. H. (2006). Bir felsefi metafor “yolda olmak”. Dinbilimleri Akademik Araştırma Dergisi, 6(1), 9-22.

Can, N. (1998). Öğretmen ve yöneticinin etkililiğinin öğretimdeki rolü. Kuram ve Uygulamada Eğitim Yönetimi, 4(1), 55-69.

Cerit, Y. (2008). Öğretmen kavramı ile ilgili metaforlara ilişkin öğrenci, öğretmen ve yöneticilerin görüşleri. Türk Ĕ̈itim Bilimleri Dergisi, 6(4), 693-712.

Erdem, F., \& Satir, C. (2000). Farklı örgütlerde kültürel yapının metaforlarla analizi. Erciyes Üniversitesi 8.Ulusal Yönetim ve Organizasyon Kongresi, 25-35.

Fleener, M. J., Pourdavood, R. G., \& Fry, P. G. (1995). A study of preservice teachers' metaphors for the different roles of the mathematics teachers. In D. T. Owens, M. K. Reed \& G. M. Millsaps (Eds.), Proceedings of the 17th Annual Meeting of the North American Chapter of the International Group for the Psychology of Mathematics Education (PME) (pp. 104-108). Columbus, OH: ERIC Clearinghouse.

Goldstein, L. B. (2005). Becoming a teacher as a hero's journey: Using metaphor in preservice teacher education. Teacher Education Quarterly, 32(1), 7-24.

Kilic, C. (2010). Belgian and Turkish pre-service primary school mathematics teachers' metaphorical thinking about mathematics. CERME 7, Rzeszow, Poland.

Kilic, C., \& Yanpar Yelken, T. (2013). Belgian and Turkish pre-service primary school teachers' metaphoric expressions about mathematics. Eurasian Journal of Educational Research, 50, 21-42.

Lakoff, G., \& Johnson, M. (1980). Metaphors we lived by. Chicago: The University of Chicago Press.

Miles, M. B., \& Huberman, A. M. (1994). Qualitative data analysis (2nd ed.). Thousand Oaks, CA: SAGE.

Noyes, A. (2004). "The poetry of the universe": New mathematics teachers' metaphoric meaning-making. In M. J. Hoines \& A. B. Fuglestad (Eds.), Inclusion and diversity: Proceedings of the 28th Conference of the International Group for the Psychology of Mathematics Education (pp. 441-448). Bergen, Norway: Bergen University College.

Ozden, Y. (1999). Ĕ̆itimde Dönüşüm Eğitimde Yeni Değerler. Ankara: PegemA Yayınları.

Parin, K. (2017). Metaforlar: Hayat, anlam ve dil. Söylem Filoloji Dergisi, 2(1), 149-151. http://dx.doi.org/10.29110/soylemdergi.313312

Saban, A. (2009). Öğretmen adaylarının öğrenci kavramına ilişkin sahip olduğu zihinsel imgeler. Türk Eğitim Bilimleri Dergisi, 7(2), 281-326.

Sahin, B. (2013). Öğretmen adaylarının "matematik öğretmeni”, "matematik” ve "matematik dersi” kavramlarına ilişkin sahip oldukları metaforik algılar. Mersin Üniversitesi Eğitim Fakültesi Dergisi, 9(1), 313-321. http://dx.doi.org/10.17860/efd.03119

Senemoglu, N. (2007). Gelişim öğrenme ve öğretim: Kuramdan uygulamaya. Ankara: Gönül Yayıncılık. 
Sengul, S., Katranci, Y., \& Gerez Cantimer, G. (2014). Ortaokul öğrencilerinin “matematik öğretmeni” kavramına ilişkin metafor algıları. The Journal of Academic Social Science Studies, 25(1), 89-111. http://dx.doi.org/10.9761/JASSS2155

Toluk Ucar, Z., Piskin, M., Akkas, E. N., \& Tasci, D. (2010). İlköğretim öğrencilerinin matematik, matematik öğretmenleri ve matematikçiler hakkındaki inançları. Eğitim ve Bilim, 35(155), 131-144.

Uzun, S., \& Palic, G. (2013). Sınıf öğretmenlerinin sınıf kavramına ilişkin sahip oldukları algıların metaforlar yardımıyla incelenmesi. Uşak Üniversitesi Sosyal Bilimler Dergisi, 16, 245-260. http://dx.doi.org/10.12780/UUSBD211

Yetim Karaca, S., \& Ada, S. (2018). Öğrencilerin matematik dersine ve matematik öğretmenine yönelik algılarının metaforlar yardımıla belirlenmesi. Kastamonu Eğitim Dergisi, 26(3), 789-800. http://dx.doi.org/10.24106/kefdergi.413327

Yildirim, A., \& Simsek, H. (2008). Sosyal bilimlerde nitel araştırma yöntemleri. Ankara: Seçkin Yayıncılık.

Yilmaz, F., Gocen, S., \& Yilmaz, F. (2013). Öğretmen adaylarının öğretmen kavramına ilişkin algıları: Bir metaforik çalışma. Mersin Üniversitesi Eğitim Fakültesi Dergisi, 9(1), 151-164. http://dx.doi.org/10.17860/efd.49273 